\title{
Assessment of the Quality of Water for Injection Marketed in South- Eastern Nigeria
}

\author{
Onyia Chukwuebuka Felix ${ }^{1}$, Ikegbunam Nkechukwu Moses ${ }^{2,3}$, Okafor Maris-stella Chibuanuli ${ }^{3}$, \\ \& Esimone Charles Okechukwu ${ }^{2}$ \\ ${ }^{1}$ Department of Biological Sciences, Godfrey Okoye University, Thinkers' Corner, Enugu \\ ${ }^{2}$ Department of Pharmaceutical Microbiology and Biotechnology, Faculty of Pharmaceutical Science, Nnamdi \\ Azikiwe University Awka, Nigeria \\ ${ }^{3}$ Molecular Research Foundation for Students and Scientists, Nnamdi Azikiwe University Awka, Nigeria \\ Correspondence: Ikegbunam Nkechukwu Moses, Department of Pharmaceutical Microbiology and Biotechnology, \\ Faculty of Pharmaceutical Science, Nnamdi Azikiwe University Awka, Nigeria. E-mail: \\ mn.ikegbunam@unizik.edu.ng
}

Received: December 18, 2018

Accepted: February 18, 2019

Online Published: February 25, 2019

doi:10.5539/ijb.v11n2p29

URL: https://doi.org/10.5539/ijb.v11n2p29

\begin{abstract}
The present work seeks to evaluate the safety and quality of water for injection (WFI) marketed in south-Eastern Nigeria. The physical, microbiological and chemical qualities of different brands of WFI marketed in southeastern Nigeria were evaluated in order to ascertain their quality. A total of one hundred and forty-seven (147) samples of four different brands of WFI (approximately thirty vials per state) were analysed. All the brands (A, B, and C) except D conformed to the $\mathrm{PH}$ range (5.0-7.0) at room temperature. The $\mathrm{PH}$ value of all the brands reduced when subjected to increased temperature. All the brands were also sterile. All the brands passed the conductivity test with respect to compendia standard. The study revealed that the various brands of WFI marketed in southeastern Nigeria conform to some official limits except for heavy metals. However, WFI in south-eastern Nigeria are considerably safe.
\end{abstract}

Keywords: Pharmaceuticals, Quality Control, Water Quality, Water, LPS (Lipopolysaccharides)

\section{Introduction}

Water is an essential ingredient of various pharmaceutical preparations, also used to clean process equipment. Thus, it plays a pivotal role in pharmaceutical processing (Hultqvist, 2007). It is, therefore, important that water should meet set standards given in different official texts. Water is the preferred vehicle because, it is well tolerated by the body, also easy to administer and has a large solvent capacity. Due to the wide variety of contaminants in mains water, water for injection must be used as the vehicle for parenteral products.

As parenteral formulations are administered directly to tissues and systemic circulations, they (including their vehicles) should not vary significantly from physiological PH (WHO, 2003).

Control of chemical purity of water for injection presents few major problems. The critical issue is that of ensuring consistent microbiological quality with respect to removal of bacteria and their endotoxins (Jahnke, 2001).

The United States pharmacopeia (USP) monograph for water for injection requires the water to: meet all the requirements for 'purified water'. That is, it must be obtained by a suitable process and purified by distilled or reverse osmosis, even equivalent method; it must meet the requirements of the bacterial endotoxin test and contains not more than 0.25 USP endotoxin units per ml; it must be prepared using suitable means to minimize microbial growth (USP, 1990).

Distillation and reverse osmosis (RO) are the only acceptable method in the United States pharmacopeia for producing water for injection. However, in the bulk pharmaceutical and biotechnological industries, ultra-filtration is employed to minimize endotoxins in those drug substances that are administered parenterally (Patterson et al., 1991). For some ophthalmic products, such as the ophthalmic irrigation solution, and some inhalation products, such as sterile water for inhalation, where there are pyrogen specifications, it is expected that water for injection be used in their formulation. However, for most inhalation and ophthalmic products, purified water is used in their 
formulation. This also applied to topical, cosmetics and oral products (Collentro, 1999). Distillation has been shown to be effective and the most reliable method in removing endotoxins from contaminated water samples $(\mathrm{pH}$. Eur., 2005). As with most processes and piece of equipment, it is good practice to know the limitations and capabilities of the equipment. For instance, stills with high levels of endotoxins in feed water have occasionally been shown to yield WFI of unacceptable Quality $(>0.25 \mathrm{EU} / \mathrm{ml})$.

Thus, this had to evaluate the quality of commercial water for injection in south-eastern Nigeria with respect to their endotoxin concentration, sterility, chemical impurities and influence of temperature.

\section{Results and Discussions}

All brands met the filled volume as claimed by their individual manufacturers. Three brands passed their PH test at varied temperature. The results of the physical qualities of the brands are presented in Table 1 below.

Table 1. Physical qualities of brands of WFI

\begin{tabular}{|c|c|c|c|c|}
\hline & Brand A & Brand B & Brand C & Sample D \\
\hline Description of container & $\begin{array}{l}\text { Sample in LTP } \\
\text { container }\end{array}$ & $\begin{array}{l}\text { Sample in LTP } \\
\text { container }\end{array}$ & $\begin{array}{l}\text { Sample in LTP } \\
\text { container }\end{array}$ & $\begin{array}{l}\text { Sample in LTSP } \\
\text { container }\end{array}$ \\
\hline $\begin{array}{l}\text { Physical appearance of } \\
\text { sample }\end{array}$ & $\begin{array}{l}\text { Clear, colourless, non- } \\
\text { viscous liquid }\end{array}$ & $\begin{array}{l}\text { Clear, colourless, non- } \\
\text { viscous liquid }\end{array}$ & $\begin{array}{l}\text { Clear, colourless, non- } \\
\text { viscous liquid }\end{array}$ & $\begin{array}{l}\text { Clear, colourless, non- } \\
\text { viscous liquid }\end{array}$ \\
\hline Filled volume (\%) & $100.00 \pm 0.00$ & $100.00 \pm 0.00$ & $111.25 \pm 5.54$ & $115.25 \pm 2.05$ \\
\hline Density $(\mathrm{g} / \mathrm{ml})$ & $0.998 \pm 0.005$ & $0.998 \pm 2.50$ & $0.994 \pm 0.000$ & $0.998 \pm 0.000$ \\
\hline $\mathrm{pH}$ at $28.9^{\circ} \mathrm{C}$ & $6.46 \pm 0.19$ & $6.39 \pm 0.06$ & $6.49 \pm 0.04$ & $7.46 \pm 0.08$ \\
\hline $\begin{array}{l}\text { Clarity/turbidity at } \\
450 \mathrm{~nm} \text { (FTU) }\end{array}$ & $0.33 \pm 0.33$ & $0.33 \pm 0.33$ & $0.30 \pm 0.88$ & $6.00 \pm 0.00$ \\
\hline
\end{tabular}

LTSP = Labelled Transparent Soft Plastic; LTP = Labelled Transparent Plastic; FTU = Formazin Turbidity Unit.

Figure 1 below depicts the effect of temperature on the $\mathrm{PH}$ of different of the samples as reduction in the $\mathrm{PH}$ with increased temperature may be attributed to leaching of certain substances from the packaging material (Marsh \& Bugusu, 2007).

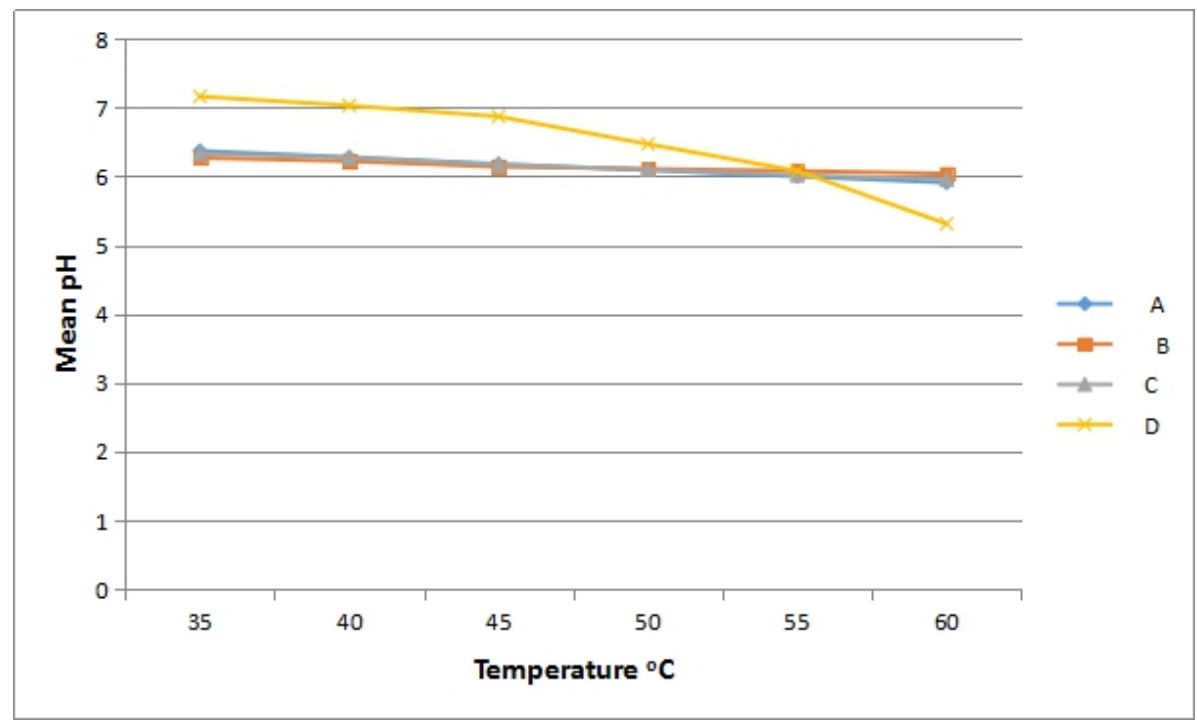

Figure 1. Effect of temperature on $\mathrm{pH}$ of sample brands

The results in Table 2 showed that all the brands of WFI were sterile which is in line with specification of the individual monographs on the production of parenterals or vehicles used for their preparation. 
Table 2. Results of sterility test on different media and Mean endotoxin concentrations of samples at $545 \mathrm{~nm}$

\begin{tabular}{|c|c|c|c|}
\hline \multirow{2}{*}{ Test sample brands } & \multicolumn{3}{|c|}{ Growth media } \\
\hline & Soybean casein & Thioglycollate & Sabouraud \\
\hline A1 & $+\mathrm{ve}$ & $+\mathrm{ve}$ & $+\mathrm{ve}$ \\
\hline A2 & $+\mathrm{ve}$ & $+\mathrm{ve}$ & $+\mathrm{ve}$ \\
\hline A3 & $+\mathrm{ve}$ & $+\mathrm{ve}$ & $+\mathrm{ve}$ \\
\hline A4 & $+\mathrm{ve}$ & $+\mathrm{ve}$ & $+\mathrm{ve}$ \\
\hline NA & $-\mathrm{ve}$ & $-\mathrm{ve}$ & -ve \\
\hline PA & $+\mathrm{ve}$ & $+\mathrm{ve}$ & $+\mathrm{ve}$ \\
\hline B1 & $+\mathrm{ve}$ & $+\mathrm{ve}$ & $+\mathrm{ve}$ \\
\hline B2 & $+\mathrm{ve}$ & $+\mathrm{ve}$ & $+\mathrm{ve}$ \\
\hline B3 & $+\mathrm{ve}$ & $+\mathrm{ve}$ & $+\mathrm{ve}$ \\
\hline B4 & $+\mathrm{ve}$ & $+\mathrm{ve}$ & $+\mathrm{ve}$ \\
\hline NB & $-\mathrm{ve}$ & $-\mathrm{ve}$ & $-\mathrm{ve}$ \\
\hline PB & $+\mathrm{ve}$ & $+\mathrm{ve}$ & $+\mathrm{ve}$ \\
\hline $\mathrm{C} 1$ & $+\mathrm{ve}$ & $+\mathrm{ve}$ & $+\mathrm{ve}$ \\
\hline $\mathrm{C} 2$ & $+\mathrm{ve}$ & $+\mathrm{ve}$ & $+\mathrm{ve}$ \\
\hline $\mathrm{C} 3$ & $+\mathrm{ve}$ & $+\mathrm{ve}$ & $+\mathrm{ve}$ \\
\hline $\mathrm{C} 4$ & $+\mathrm{ve}$ & $+\mathrm{ve}$ & $+\mathrm{ve}$ \\
\hline $\mathrm{NC}$ & $-\mathrm{ve}$ & $-\mathrm{ve}$ & -ve \\
\hline $\mathrm{PC}$ & $+\mathrm{ve}$ & $+\mathrm{ve}$ & $+\mathrm{ve}$ \\
\hline D1 & $+\mathrm{ve}$ & $+\mathrm{ve}$ & $+\mathrm{ve}$ \\
\hline D2 & $+\mathrm{ve}$ & $+\mathrm{ve}$ & $+\mathrm{ve}$ \\
\hline D3 & $+\mathrm{ve}$ & $+\mathrm{ve}$ & $+\mathrm{ve}$ \\
\hline D4 & $+\mathrm{ve}$ & $+\mathrm{ve}$ & $+\mathrm{ve}$ \\
\hline ND & $-\mathrm{ve}$ & $-\mathrm{ve}$ & -ve \\
\hline $\mathrm{PD}$ & $+\mathrm{ve}$ & $+\mathrm{ve}$ & $+\mathrm{ve}$ \\
\hline Sample & \multicolumn{3}{|c|}{ Mean endotoxin concentration (EU/ml) } \\
\hline A & \multicolumn{3}{|c|}{$-0.0360 \pm 0.0001$} \\
\hline B & \multicolumn{3}{|c|}{$-0.0360 \pm 0.0000$} \\
\hline $\mathrm{C}$ & \multicolumn{3}{|c|}{$-0.036 \pm 6.25 \mathrm{E}-05$} \\
\hline $\mathrm{D}$ & \multicolumn{3}{|c|}{$-0.0060 \pm 0.0008$} \\
\hline
\end{tabular}

Table 2 shows the mean endotoxin concentration of different brands of WFI. All brands passed the endotoxin test since they have their mean concentration below the specified limit $(0.25 \mathrm{EU} / \mathrm{ml})$.

Figure 2 depicts the concentration of heavy metals in the sample. Cadmium was observed to be of high concentration in sample brand $\mathrm{D}$ whereas chromium was observed to be at least level of concentration. According to USP, the concentration of heavy metals collectively should be less than or equal to $0.1 \mathrm{ppm}$.

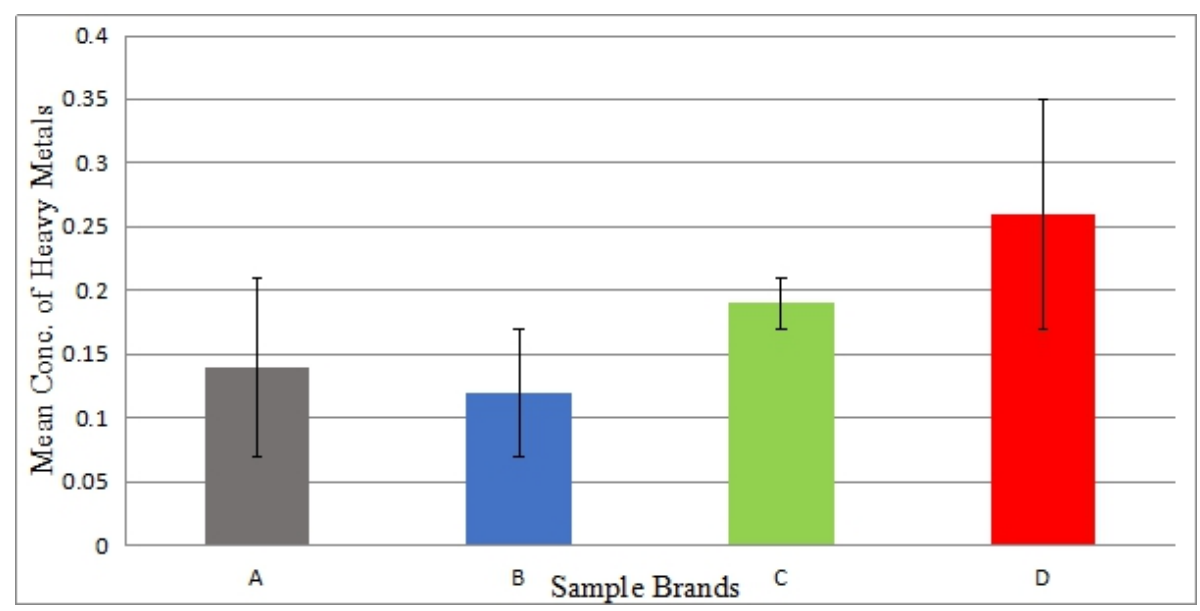

Figure 2. Mean concentration of heavy metals in sample brands with their \pm SEM 
All the samples passed the conductivity test analysed on them as they conformed to the specified limit $(\leq 1.3 \mu \mathrm{s} / \mathrm{cm}$ at $25^{\circ} \mathrm{C}$ ) as shown in Figure 3 below.

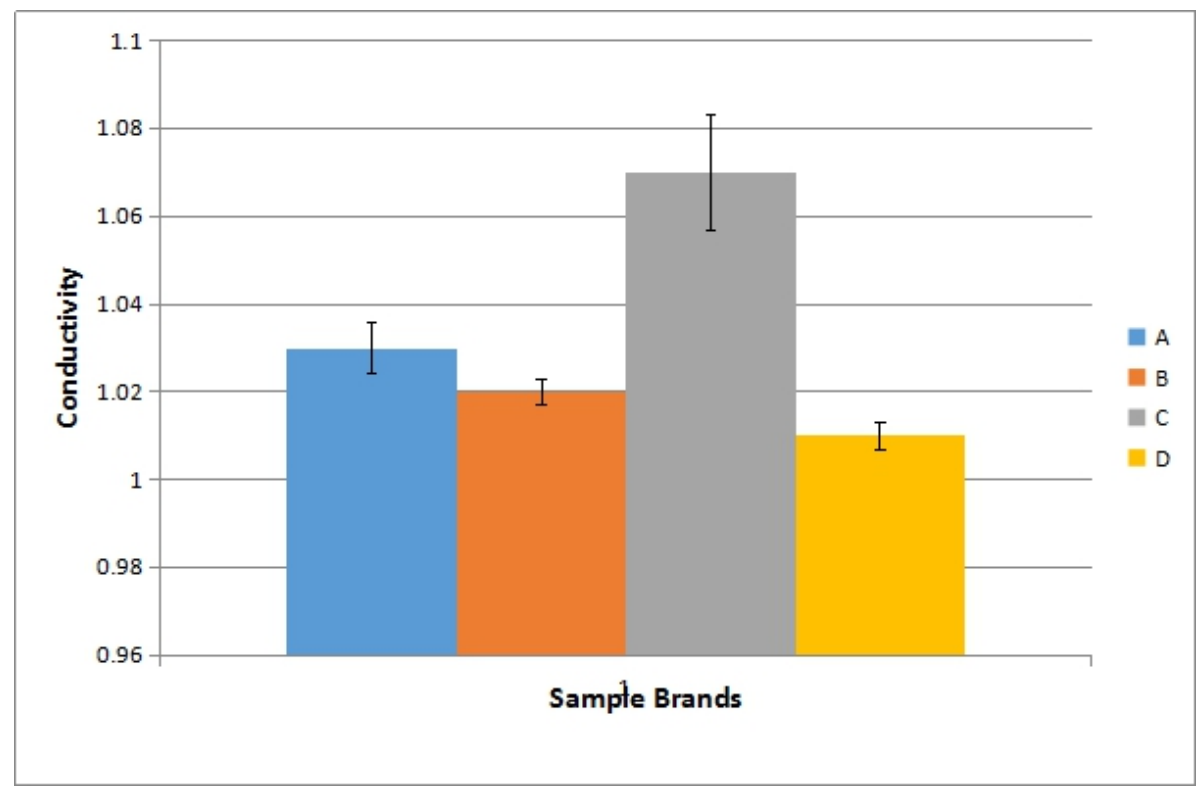

Figure 3. Conductivity of samples at room temperature

All the brands met the filled volume as claimed by their individual manufacturers. Though brands A and B had the exact $10 \mathrm{ml}$ volume whereas brands $\mathrm{C}$ and $\mathrm{D}$ had their volumes above the $10 \mathrm{ml}$ volume as claimed by their manufacturers. However, the later agrees more with USP specifications on single dose preparation which should contain sufficient volume of injection readily to permit the withdrawal and administration of the volume specified on the label (Okore, 2009).

Brands A, B, and C passed their $\mathrm{pH}$ test at different temperature except brand D. This suggests the use of sound purification systems during purification and pre-treatment of pharmaceutical water used in the production of WFI or that the feed water used complied with the WHO/EPA guidelines on drinking water. This entails that the water should contain small and safe quantities of potentially objectionable chemical species that are easily removed during pre- treatment stage (EPA., 2009). For brand D, it could be that the feed water contained large quantities of chemical species that are of alkaline origin which brings about pollution of the purification and pre-treatment systems thereby preventing total removal (Okonkwo \& Eboatu, 1999).

The reduction in the $\mathrm{pH}$ of samples may be attributed to leaching of certain substances from the packaging material (Marsh \& Bugusu, 2007). The compound on which most concern have focused on are bisphenol A (known as BPA) which is used in polycarbonate products and epoxy resins that line tin cans, and a group of plastic softer called phthalates (Goulas et al., 2008).

Pharmaceuticals should at all times be stored under the recommended conditions, as stated by manufacturing company. Thus, preventing contamination and deterioration of the product (BP, 2009). However, none of the sample brands had their $\mathrm{pH}$ value below 5.0 when subjected to varied temperature. Therefore, they may not pose threat to life when admixed with any of the pharmaceutical products.

That all the brands passed the endotoxin test probably suggests the use of distillation (a purification process) as specified in USP and Ph. Eur monographs (Table 2), as being effective in eliminating these heat labile, non-volatile lipopolysaccharides (Henry, 2009).

All the brands passed the sterility test, which suggests that proper sterilisation process was strictly adhered to during pre -treatment of the source water used in their production. Also, there could be reduction if not entirely absence of pipe dead legs during construction of the stainless pipes. It also suggests adequate and proper sanitisation of the purification and pre -treatment systems used in their environment.

None of the samples passed the heavy metal tests and this suggests that there could be a serious environmental 
effect of heavy metal on the water body where the source water is gotten. Consequently, its high availability may foul the efficiency of the pre -treatment systems used in during production. Contamination of these products by heavy metals and alkaline chemicals is influenced by environmental pollution through source water (Okonkwo \& Eboatu, 1999).

All the samples also passed the conductivity test analysed on them as they conform to the specified limit $(\leq$ $1.3 \mu \mathrm{s} / \mathrm{cm}$ at $25^{\circ} \mathrm{C}$ ) as stated in the individual monographs on WFI. This suggests reduction in the chemical impurities in source water which was easily removed during pre-treatment stage. However, this contradicts a study conducted by Nduka and Olisakwe (2007) physicochemical parameters and contaminants in Warri metropolitan's water supply. Heavy metals were found to be of lowest concentration in bore hole water supplies, except their acidic $\mathrm{pH}$ values, well water samples were found to have high conductivity.

In all, the comparison of these brands, based on their quality with respect to the specified limits on WFI from the Chi-square distribution at $95 \%$ significant level suggests that, they are not significantly different.

\section{Materials and Methods}

The sample size was determined by cumulative distribution function. $\mathrm{Xi}, \mathrm{i}=1,2 \ldots \mathrm{n}$ were independent observations taken from a normal distribution with unknown mean $\mu$ and known variance $\sigma 2$. Two hypotheses were considered, a null hypothesis: $\mathrm{H} 0: \mu=0$ and an alternative hypothesis: $\mathrm{H} 1: \mu=\mu^{*}$

\subsection{Determination of Physical Qualities}

Samples and their packages were observed, their label, colour and nature of content were noted.

Filled volume was carried out by dividing measured volume with claimed volume before multiplying by 100 percent. Density was also carried out by dividing the exact weight of $1 \mathrm{ml}$ of the samples with their respective volume $(1 \mathrm{ml})$. The $\mathrm{PH}$ at different temperature (including the room temperature) were determined using $\mathrm{PH}$ meter and water bath.

\subsection{Determination of Microbiological Qualities}

\subsubsection{Endotoxin Test}

Endotoxin concentration of the samples were evaluated. The sample and reagent preparation were done according to the manufacturer's specifications. Hundred micro litters of each of the dilutions were dispersed into endotoxin free vials, mixed thoroughly for 30 seconds with a vortexer. Hundred microliters of reagent water were dispensed into endotoxin free vials in replicates. Hundred microliters of reconstituted limulus amoebocyte lysate were added to each vial. They were incubated again for 45 minutes at $37 \pm 1^{\circ} \mathrm{C}$. Then hundred microliters of reconstituted chromogenic substrate solution was added to each vial, swirled gently avoiding foaming. They were incubated again for 6 minutes at $37 \pm 1^{\circ} \mathrm{C}$. Five hundred microliters of $25 \%$ acetic acid in endotoxin free water was added to the vials after incubation. The absorbance of each reaction vial was read at $545 \mathrm{~nm}$.

\subsubsection{Sterility Testing}

The sterility of the test samples were evaluated using direct inoculation on three different media namely: soybean casein digest, fluid thioglycollate and sabouraud media. A twenty-four-hour culture of test organisms were carried out to ensure the nutritive strength of the broth media in enhancing the growth of test organisms used. Double strength media were prepared and kept for 48 hours at $37^{\circ} \mathrm{C}$ before use to check for chance contamination. The samples were aseptically transferred into the broth media under biosafety cabinet. Control tests were carried out at same time and all were incubated according to their requirements.

\subsection{Determination of Chemical Qualities}

Heavy metals were first analysed using spectrophotometer at different wavelengths. The heavy metals analysed include: mercury at $574 \mathrm{~nm}$, cadmium at $576 \mathrm{~nm}$, chromium at $540 \mathrm{~nm}$, and lead at $514 \mathrm{~nm}$. Inorganic impurities were determined using temperature/conductivity meter.

\section{Data Analysis}

The data were analysed using Chi-square distribution at 95\% level of significance and regression analysis.

\section{Acknowledgements}

The entire staff of the Department of Pharmaceutical Microbiology and Biotechnology, and South East Zonal Laboratory of NAFDAC, Nigeria were acknowledged.

\section{Authors Contribution}

OCF, INM, and OMC developed the manuscript with the statistical analysis involved. INM and ECO conceived 
and designed the experiment. OCF performed the experiment.

\section{Conflict of interests}

The authors declare that there is no conflict of interests regarding the publication of this paper.

\section{References}

British Pharmacopeia. (2009). British Pharmacopeia Commission Secretariat of the Medicines and Health care Products Regulatory Agency, 2, 1141-1142, 1149.

Collentro, W. (1999). Pharmaceutical Water, System Design, Operation and Validation. Inter Press Inc. Buffalo Government, 19-26.

Henry, R., Murakami, S., \& Weiss, S. (1997). Cleaning Mechanism Study for Biopharm. Plant Design, Pharm. Engineering, 8-21.

Hultqvist, A. (2007). Practical Guidelines for Qualification of Purified Water Systems. Pharm. Technol. Europe., 19(12).

Jahnke, M. (2001). One-way Distribution System for Water for Injection. Process Microbiological Quality Control and Meeting Regulatory Requirements. PDA Journal of Pharmaceutical Science and Technology, 55(1), 39.

Marsh, K., \& Bugusu, B. (2007). Food Packaging-Robs Materials and Environmental Issues. Journal of Food Science, 72(3), R39-R55.

Nduka, J. K., \& Olisakwe, O. E. (2007). Heavy Metal Levels and Physiochemical Quality of Potable Water Suply I Warri, Nigeria. Pure and Industrial Chemistry Department, Nnamdi Azikiwe University, Awka-Anambra State Nigeria, 97(9), 867-874.

Okonkwo, E. M., \& Eboatu, A. N. (1999). Environmental Pollution and Degradation (2nd ed., pp. 1-17). Onis Excel Creation Ltd.

Okore, V. C. (2009). Principles of Pharmaceutical Microbiology (2nd ed., pp. 344-348). Ephrata Publisher Nigeria.

Pahwa, R., Khatri, S., Rathour, A., \& Lamba, H. S. (2004). Validation of Moist Heat Sterilisation Cycles. J. Sci. Pharm, 5(4), 125-130.

USP XX11. (1990). The National Formulary, NFXVII, United States Pharmacopoeia Convention, 12601 Twin book Parkway, Rock Ville.

WHO. (2003). WHO Expert Committee on Specifications for Pharmaceutical Preparations. Thirty Seven Report Geneva, No 908 Anenex 4.

\section{Copyrights}

Copyright for this article is retained by the author(s), with first publication rights granted to the journal.

This is an open-access article distributed under the terms and conditions of the Creative Commons Attribution license (http://creativecommons.org/licenses/by/4.0/). 